\title{
What is Damaging Our Tissues and Lives?
}

\begin{abstract}
Ciampolini $\mathbf{M}^{*}$
Preventive Gastroenterology Unit, Department of Paediatrics, Università di Firenze, Italy
\end{abstract}

*Corresponding author: Mario Ciampolini, Preventive Gastroenterology Unit,

\section{Editorial}

Volume 3 Issue 2

Received Date: February 12, 2018

Published Date: February 19, 2018

Department of Paediatrics, Università di Firenze, retired 50132 Florence, Italy, Email: mlciampolini@fastwebnet.it

Keywords: Blood Glucose; Diabetes; Insulin resistance; Overweight; Fattening; Energy balance; Energy intake; Limit in Energy Intake; Hunger; Meal Onset; Energy Availability; Bowel disorders; Malnutrition; ORCID 00000002-8102-2302

\section{Editorial}

Viruses, parasites and bacteria destroy cell and tissues by direct action and indirectly eliciting inflammation. Allergy and insulin resistance worsen and maintain inflammation. Blood glucose (BG) does this directly (?) and provoking unwanted reflexes. Lipids, mainly cholesterol sustain vascular diseases (or only mark damages?). Hypertension signals and contributes to vascular diseases. I prefer to think to a unique final way of damaging: the immune mechanisms of damage. Immune cells and antibodies are predisposed to destroy molecules or structures that are born outside the human body and are demolished in all tissues. These events develop also in the respiratory activity. Absorptive function is so important that is preserved by transferring these immune molecules or structures in all body tissues for elimination. Intestinal mucosa retains the killing function to limit the outside aggression. Killing invading viruses or bacteria marks the start of convalescence. High energy availability and high Blood Glucose (BG) produce a similar state of convalescence and of poor health through reflexes [1-21]. Digestion becomes slow and immunogenic bacteria increase in number, including immunogenic species. More than half immune body cells reside in intestinal mucosa. These immune cells kill bacteria but do not eliminate biochemical components of bacteria. Antigens spread throughout the body eliciting or increasing local, initial, silent inflammations mainly in vascular sites. The inflammatory settlements produce infarctions and (in the long term) malignances. This insight ceases to be an academician's exercise if we conceive plasma cholesterol as a molecule that often is useful. Cholesterol constitute about half cell membranes. It may signal the unpleasant circumstance of an expanding inflammation and of an active cell proliferation as well as showing an excess lipid or saturated lipids intake. We may wish to have low plasma cholesterol, although diminishing its plasma level by drugs appears to be no more effective than head immersion by a strut. This opinion derives from findings of no decrease of mortality by drug lowering plasma cholesterol. Instead, I always obtained recovery of intestinal and also bronchial disorders after assuming that relapses were due to increased stimulation of bowel mucosa. I eliminated any permanence of nutrients in the bowel by eating suspension until Initial Hunger arousal: this was the powerful factor in recovery. This assumption is useful to spare money in illusory drugs like statins [2224].

\section{Acknowledgements}

The Author acknowledges the indispensable collaboration in writing with David Lowel-Smith (NZ) and Riccardo Bianchi (NY), and the strategic, statistical support by Cutberto Garza (Rector, Boston College), Giuliano Parrini (Professor of Physics, Firenze) and Andrea Giommi (Professor of Statistics, Firenze).

The here summarized researches were supported by the Italian Ministry of University, Research, Science and Technology grants for the years 1998-2002 and by ONLUS Nutrizione e Prevenzione, Firenze, for the years 20032012. This review has been shown in: "Modifying Eating Behavior: Novel Approaches for Reducing Body Weight, Preventing Weight Regain and Reducing Chronic Disease Risk" ASN's Annual Meeting \& Scientific Sessions at Experimental Biology 2014, April 26-30.Moreover in 


\section{Psychology \& Psychological Research International Journal}

Rome 2015, London 2016, Milano 2017. No Conflict of Interests.

\section{This Editorial is Supported by the Following Video}

Meal by meal energy balance and level in blood and body tissues

This video is helpful to those who have poor health and want to learn sensations of hunger and sensations of lowering blood glucose. Three events per day are associated with a decrease of energy intake (20\%-30\%) and mean BG. Three lowering events per day as a habit diminish overall inflammation, suppress functional disorders, fattening/insulin resistance and prevent vascular and malignant diseases. The National Children's Study- N Engl J Med (2015) 372: 1486-1487: Obesity, diabetes, asthma, autism, birth defects, dyslexia, attention deficit-hyperactivity disorder, schizophrenia has increased in children in the last half century. We attribute these increases to expanded overall inflammation that starts with an increase of bacteria and bacteria species in small intestine.

The complete (is completeness possible in Medicine?) assumption is reported in the enclosed Video. I can provide all references that are not reported in the video. A feedback of whatever nature is welcomed.

\section{References}

1. Mowat AM (1987) The cellular basis of gastrointestinal immunity. In: Marsh MN (Ed.) Immunopathology of the small intestine. John Wiley \& Sons, Chichester pp: 44.

2. Brandtzaeg P, Halstensen TS, Kett K, Krajci P, Kvale D, et al. (1989) Immunobiology and Immunopathology of Human Gut Mucosa: Humoral Immunity and Intraepithelial Lymphocytes. Gastroenterology 97(6): 1562-1584.

3. Abrams GD (1977) Microbial effects on mucosal structure and function. Am J Clin Nutr 30(11): 18801886.

4. Hungate RE (1967) Ruminal fermentation. In: Heidel W, Code CF, Handbook of Physiology, sect 6, Alimentary canal. Washington DC: Am Physiol Soc, pp: 2725-2746.
5. Ciampolini M, Bini S, Orsi A (1996) Microflora persistence on duodenojejunal flat or normal mucosa in time after a meal in children. Physiol Behav 60(6): 1551-1556.

6. Ciampolini M, Borselli L, Giannellini V (2000) Attention to Metabolic Hunger and Its Effects on Helicobacter Pylori Infection. Physiol Behav 70(3-4): 287-296.

7. Cooper IF, Siadaty MS (2014) 'Bacteriums' associated with 'Blood Glucose Level Finding'. Bio Med Lib Review.

8. Mccoy KD, Köller Y (2015) New developments providing mechanistic insight into the impact of the microbiota on allergic disease. Clin Immunology 159(2): 170-176.

9. Kristensen VN (2017) The antigenicity of the tumor cell. N Engl J Med 376(5): 491-493.

10. Reaven GM (1988) Role of Insulin Resistance in Human Disease. Banting Lecture 1988. Diabetes 37(12): 1595-1607.

11. Brandtzaeg P, Halstensen TS, Kett K, Krajci P, Kvale D, et al. (1989) Immunobiology and Immunopathology of Human Gut Mucosa: Humoral Immunity and Intraepithelial Lymphocytes. Gastroenterology 97(6): 1562-1584.

12. Hecht G (2007) In the Beginning Was Helicobacter pylori: Roles for Microbes in Other Intestinal Disorders. Gastroenterology 132(2): 481-483.

13. Festa A, D'Agostino Jr R, Howard G, Mykkanen L, Russell PT, et al. (2000) Chronic Subclinical Inflammation as Part of the Insulin Resistance Syndrome: The Insulin Resistance Atherosclerosis Study (IRAS). Circulation 102(1): 42-47.

14. Reaven GM (2006) The Metabolic Syndrome: Is This Diagnosis Necessary? American Journal of Clinical Nutrition 83: 1237-1247.

15. Smith CW (2007) Diet and Leukocytes. American Journal of Clinical Nutrition 86(5): 1257-1258.

16. Bigorgne AE, Bouchet-Delbos L, Naveau S, Dagher I, Prevot S, et al. (2008) Obesity-Induced Lymphocyte Hyperresponsiveness to Chemokines: A New Mechanism of Fatty Liver Inflammation in Obese Mice. Gastroenterology 134(5): 1459-1469. 


\section{Psychology \& Psychological Research International Journal}

17. Cani PD, Amar J, Iglesias MA, Poggi M, Knauf C, et al. (2007) Metabolicendotoxemia Initiates Obesity and Insulin Resistance. Diabetes 56(7): 1761-1767.

18. Stratton IM, Adler AI, Neil HAW, Yudkin JS, Matthews DR, et al. (2000) Association of Glycaemia with Macrovascular and Microvascular Complications of Type 2 Diabetes (UKPDS 35): Prospective Observational Study. British Medical Journal 321(7258): 405-412.

19. Bruun JM, Verdich C, Toubro S, Astrup A, Richelsen B (2003) Association between Measures of Insulin Sensitivity and Circulating Levels of Interleukin-8, Interleukin-6 and Tumor Necrosis Factor-Alpha. Effect of Weight Loss in Obese Men. Eur J Endocrinol 148(5): 535-542.

20. Bragg F, Li L, Smith M, Guo Y, Chen Y, et al. (2014) Associations of Blood Glucose and Prevalent Diabetes with Risk of Cardiovascular Disease in 500,000 Adult Chinese: The China Kadoorie Biobank. Diabetic Medicine 31: 540-551.

21. Kubes P, Meahl WZ (2012) Sterile Inflammation in the Liver. Gastroenterlogy 143(5): 1158-1172.

22. Calle EE, Rodriguez C, Walker-Thurmond K, Thun MJ (2003) Overweight, Obesity, and Mortality from Cancer in a Prospectively Studied Cohort of U.S. Adults. N Engl J Med 348(17): 1625-1638.

23. Fontana L, Klein S, Holloszy JO (2006) Long-Term Low-Protein, Low-Calorie Diet and Endurance Exercise Modulate Metabolic Factors Associated with Cancer Risk. The American Journal of Clinical Nutrition 84(6): 1456-1462.

24. Landrigan PJ, Baker B (2015) The National Children's Study-End or New Beginning? N Engl J Med 372(16): 1486-1487. 